\title{
Methyloversatilis universalis gen. nov., sp. nov., a novel taxon within the Betaproteobacteria represented by three methylotrophic isolates
}

\author{
Correspondence \\ Ludmila Chistoserdova \\ milachis@u.washington.edu
}

\author{
Marina G. Kalyuzhnaya, ${ }^{1} \dagger$ Paolo De Marco, ${ }^{2} \dagger$ Sarah Bowerman, ${ }^{3}$ \\ Catarina C. Pacheco, ${ }^{2}$ Jimmie C. Lara, ${ }^{4}$ Mary E. Lidstrom ${ }^{1,4}$ \\ and Ludmila Chistoserdova ${ }^{1}$ \\ ${ }^{1,3,4}$ Departments of Chemical Engineering ${ }^{1}$, Biology ${ }^{3}$ and Microbiology ${ }^{4}$, University of \\ Washington, Seattle, WA 98195, USA \\ ${ }^{2}$ Instituto de Biologia Molecular e Celular, Universidade do Porto, R. Campo Alegre, 823, \\ 4150-180 Porto, Portugal
}

\begin{abstract}
The taxonomic positions and phylogenetic relationships of two new methylotrophic isolates from Lake Washington (USA) sediment, $\mathrm{FAM}^{\top}$ and 500 , and the previously described methylotrophic strain EHg5 isolated from contaminated soil in Estarreja (Portugal) were investigated. All three strains were facultative methylotrophs capable of growth on a variety of $\mathrm{C}_{1}$ and multicarbon compounds. Optimal growth occurred at $\mathrm{pH} 7 \cdot 5-8$ and $30-37{ }^{\circ} \mathrm{C}$. The major fatty acids were $\mathrm{C}_{16: 1} \omega 7 \mathrm{c}$ and $\mathrm{C}_{16: 0}$. The major quinone was ubiquinone $\mathrm{Q} 8$. Neither methanol dehydrogenase nor methanol oxidase activities were detectable in cells grown on methanol, suggesting an alternative, as-yet unknown, mechanism for methanol oxidation. The isolates assimilated $\mathrm{C}_{1}$ units at the level of formaldehyde, via the serine cycle. The DNA G $+\mathrm{C}$ content of the strains ranged between 64 and 65 mol\%. 16S rRNA gene sequence similarity between the three new isolates was $99 \cdot 85-100 \%$, but was below $94 \%$ with other members of the Betaproteobacteria, indicating that the isolates represent a novel taxon. Based on physiological, phenotypic and genomic characteristics of the three isolates, a new genus, Methyloversatilis gen. nov., is proposed within the family Rhodocyclaceae. The type strain of Methyloversatilis universalis gen. nov., sp. nov. is $\mathrm{FAM}^{\top}$ $\left(=\right.$ CCUG $52030^{\top}=$ JCM $\left.13912^{\top}\right)$.
\end{abstract}

Methylotrophs are micro-organisms that are able to grow on single-carbon compounds. Methylotrophy is widespread within the bacterial world and is found within members of the Alphaproteobacteria, Betaproteobacteria and Gammaproteobacteria and members of the Firmicutes (Lidstrom, 2001). Culture-independent approaches to evaluate the potential for methylotrophy in freshwater Lake Washington (Washington State, USA), via detection and analysis of the genes for tetrahydromethanopterinlinked formaldehyde oxidation ( $f a e$ and $f h c D$ ), have suggested the presence of species not closely related to known methylotrophs, based on gene sequence divergence (Kalyuzhnaya et al., 2004, 2005; Nercessian et al., 2005). This paper describes isolation of pure cultures of two bacterial

†These authors contributed equally to this work.

Abbreviations: LWW, Lake Washington water; RuMP, ribulose monophosphate; SXT, sulphamethoxazole plus trimethoprim.

The GenBank/EMBL/DDBJ accession numbers for the 16S rRNA, fae and $t h c D$ gene sequences of strain $\mathrm{FAM}^{\mathrm{T}}$ are DQ442273, DQ457109 and DQ457110, and that for the 16S rRNA gene sequence of strain 500 is DQ923115. strains from Lake Washington (designated $\mathrm{FAM} 5^{\mathrm{T}}$ and 500) possessing divergent methylotrophy genes, and their comparison with a previously described strain (EHg5).

Strain EHg5 was isolated from soil contaminated with chemical industrial wastes (Estarreja, Portugal), after enrichment on methanol, as described by De Marco et al. (2004). Strains FAM5 ${ }^{\mathrm{T}}$ and 500 were isolated from the top layer of Lake Washington sediment as part of the present study. Sediment samples were collected from a 63-m-deep site as described previously (Kalyuzhnaya et al., 2004). Samples $(1 \mathrm{ml})$ of the upper $1.0 \mathrm{~cm}$ of the sediment were inoculated into $250-\mathrm{ml}$ flasks containing $50 \mathrm{ml}$ filtered $(0 \cdot 22-\mu \mathrm{m}$ filter; Millipore) Lake Washington water (LWW) supplemented with $5 \mathrm{mM}$ formaldehyde solution $(37 \%$ formaldehyde stock solution stabilized with 10-15\% methanol; Fisher Scientific). The flasks were incubated for 2-3 weeks at room temperature with shaking (125 r.p.m.). In subsequent enrichments, $10 \mathrm{ml}$ of the previous enrichment culture was diluted $1: 10$ (to a total of $50 \mathrm{ml}$ ) in the same medium. Flasks were incubated at room temperature with shaking for 1 week. Strain $\mathrm{FAM}^{\mathrm{T}}$ was obtained as a 
colony after the third enrichment culture was plated onto a solid medium (LWW solidified with $1.8 \%$ Bacto agar and supplemented with $10 \mathrm{mM}$ formaldehyde solution) and incubated at room temperature for 1 week. The isolate was further purified by triplicate streaking on LWW agar supplemented with $0 \cdot 1 \%$ methanol. Strain 500 was obtained from the same sediment sample as follows. A sediment sample $(5 \mathrm{ml})$ was homogenized for 5 min by using a PRO 200 homogenizer (at setting 3; Pro Scientific Inc.) and diluted in LWW (to obtain 1-10 cells per $200 \mu \mathrm{l}$ ) supplemented with $5 \mathrm{mM}$ formaldehyde solution. The diluted samples were transferred into 96-well microplates $(200 \mu \mathrm{l}$ per well) and the microplates were covered with lids and incubated for up to 3 months at room temperature. Microplate wells were routinely checked visually, and the contents of those showing microbial growth were transferred to $5 \mathrm{ml} \mathrm{LWW}$ supplemented with formaldehyde and plated on LWW agar medium supplemented with $0 \cdot 1 \%$ methanol. Pure cultures were obtained by streaking the resulting colonies onto fivefold-diluted basal mineral medium (Harder et al., 1973) supplemented with vitamin $B_{12}\left(0 \cdot 1 \mu \mathrm{g} \mathrm{ml}^{-1}\right)$. Vitamin $B_{12}$ dependence is widespread within the Betaproteobacteria (Willems et al., 1992), and a vitamin-dependent pattern of the cultures in question was initially observed based on their association on plates with potentially $\mathrm{B}_{12}$-producing alphaproteobacteria (data not shown). The purity of the cultures was monitored by microscopy and by growth tests using media with and without vitamin $B_{12}$.

All strains were routinely grown in basal salts medium supplemented with $0 \cdot 1 \%$ methanol and vitamin $B_{12}$. Negatively stained preparations and thin sections of cells of strain FAM $5^{\mathrm{T}}$ were viewed using a 1200 Ex II transmission electron microscope (JEOL) at an operating voltage of $80 \mathrm{kV}$. For long-term storage at $-80^{\circ} \mathrm{C}$, cells were suspended in the basal salts medium supplemented with $10 \%$ DMSO. Phenotypic characterization of the isolates was performed as described by Smibert \& Krieg (1994). Growth rates were determined by monitoring cell density at $600 \mathrm{~nm}$ using a Bioscreen C plate reader (MBR) or in 5-ml tube or 250-ml flask bulk cultures. Specific growth rates were calculated as means of triplicate determinations. The optimal concentration of methanol for growth was tested using the plate reader at the following concentrations $(\mathrm{v} / \mathrm{v})$ : $0 \cdot 01,0 \cdot 05,0 \cdot 1,0 \cdot 2,0 \cdot 3,0 \cdot 5,1,2,3,4$ and $5 \%$. All other substrates were tested at a concentration of $0 \cdot 1 \%(\mathrm{w} / \mathrm{v})$. The following substrates were tested as carbon sources: methylamine, dimethylamine, trimethylamine, methylsuccinate, formaldehyde, formate, vanillin, choline, betaine, sarcosine, oxalate, acetate, pyruvate, glycolate, citrate, malate, succinate, glucose, maltose, fructose, mannitol, ethanol, acetone, toluene, glycerol, serine, alanine, asparagine, arginine and aspartate. The following substrates were tested as nitrogen sources: $\mathrm{KNO}_{3}, \mathrm{NH}_{4} \mathrm{Cl}$, methylamine, dimethylamine, trimethylamine, guanidine, glycine, serine, valine, alanine, cysteine, asparagine, aspartate, arginine, methionine, histidine, proline, glutamate, phenylalanine, tryptophan, peptone, yeast extract, threonine, urea and $\mathrm{N}_{2}$. Sensitivity to antibiotics was examined by spreading cells onto basal mineral medium agar plates and placing onto them Difco discs that contained a variety of antibiotics (see below). The effect of antibiotics on cell growth was assessed after 1 week of incubation. Cellular phospholipid fatty acid analyses were performed by the CCUG, University of Göteborg, Sweden. Analyses of the respiratory quinones were carried out by the Identification Service of the DSMZ (Braunschweig, Germany). Chromosomal DNA was extracted and purified as described previously (Kalyuzhnaya et al., 2005a). The $\mathrm{G}+\mathrm{C}$ content was determined by HPLC separation as described by Tamaoka \& Komagata (1984). DNA-DNA hybridization experiments were performed using the competition procedure described by Johnson (1994). 16S rRNA gene fragments were amplified as described by Lane (1991) and sequenced using the BigDye 3.1 termination sequencing kit (Applied Biosystems). Reaction analyses were performed by the Department of Biochemistry Sequencing Facility at the University of Washington. DNA sequences were aligned using the CLUSTAL W program (Higgins et al., 1996). Phylogenetic analysis was carried out using the PHYLIP package (Felsenstein, 2003). The distance method was employed, and 100 bootstrap analyses were performed.

Cells of strains EHg5, FAM5 ${ }^{\mathrm{T}}$ and 500 were Gram-negative, straight or slightly curved rods $(1 \cdot 2 \pm 0 \cdot 4 \times 0 \cdot 4 \pm 0 \cdot 1 \mu \mathrm{m})$ (Fig. 1). Cells were non-motile, reproduced by binary fission and did not form resting bodies. Colonies of isolates $\mathrm{FAM}^{\mathrm{T}}$ and 500 were white (turning brown with age), circular, convex, brittle and up to $2 \mathrm{~mm}$ in diameter. In liquid cultures, cells of these strains tended to clump

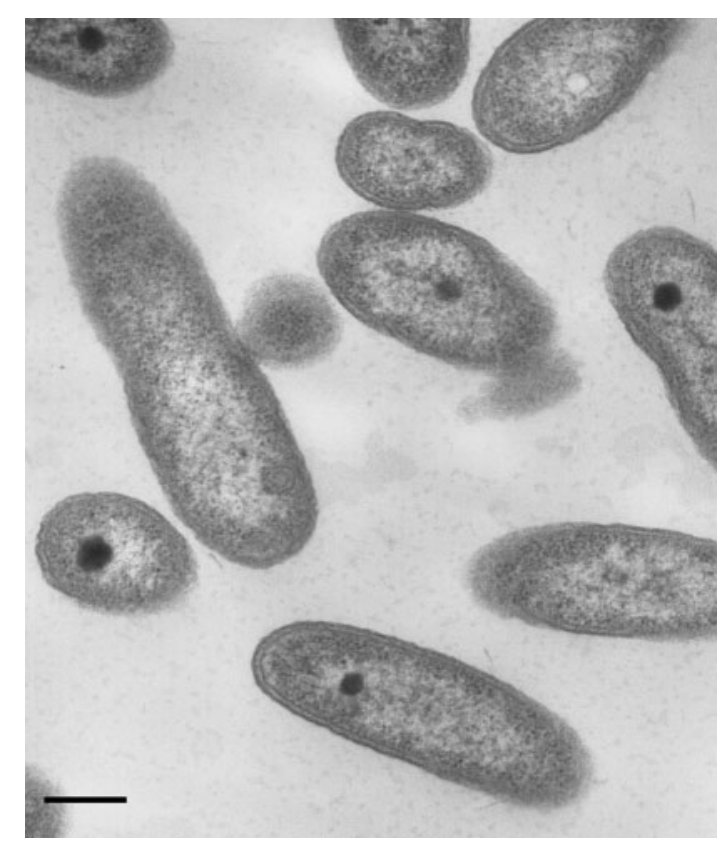

Fig. 1. Electron micrograph of thin-sectioned cells of strain FAM5 ${ }^{\top}$ showing the cell wall. Bar, $0.25 \mu \mathrm{m}$. 
together, forming white flakes. Isolate $\mathrm{EHg} 5$ formed circular colonies, $1-2 \mathrm{~mm}$ in diameter, that were caramel in colour, circular and smooth. Cells of strain EHg5 did not form aggregates in liquid culture. All isolates required vitamin $B_{12}$ for growth. The isolates were able to use all the substrates tested (see above) with the following exceptions. Strain FAM $5^{\mathrm{T}}$ did not use acetate, pyruvate or aspartate as carbon sources or alanine, cysteine or $\mathrm{N}_{2}$ as nitrogen sources. Strain 500 did not use mannitol or aspartate as carbon sources or $\mathrm{KNO}_{3}$, phenylalanine, tryptophan or $\mathrm{N}_{2}$ as nitrogen sources. Strain EHg5 did not utilize vanillin, choline, sarcosine, oxalate, acetate or mannitol as carbon sources or cysteine, asparagine, aspartate, histidine, proline, glutamate, peptone, yeast extract, threonine or $\mathrm{N}_{2}$ as nitrogen sources. All three isolates grew in the presence of up to $5 \%$ methanol, the maximal growth rate occurring at $0 \cdot 05-1 \%$ methanol (isolate $\mathrm{EHg} 5$ ) or $0 \cdot 01-0 \cdot 1 \%$ (isolates $\mathrm{FAM}^{\mathrm{T}}$ and 500 ). $\mathrm{pH}$ and temperature optima were tested in liquid basal medium supplemented with $0 \cdot 1 \%$ methanol. Growth occurred at $\mathrm{pH} 6 \cdot 5-9$, with optimum growth at $\mathrm{pH} 7 \cdot 5$ (isolate EHg5) or 8.0 (isolates FAM5 ${ }^{\mathrm{T}}$ and 500 ). The isolates grew within a temperature range of $10-42^{\circ} \mathrm{C}$, with optimum growth at $37^{\circ} \mathrm{C}$ (isolates $\mathrm{FAM} 5^{\mathrm{T}}$ and $\mathrm{EHg} 5$ ) or $30^{\circ} \mathrm{C}$ (isolate 500). The strains were oxidase- and catalasepositive. Tests for nitrate reduction, urease activity, sugar fermentation and indole production were negative. All isolates were resistant to $\left(\mu \mathrm{g} \mathrm{ml}^{-1}\right)$ ampicillin (10), erythromycin (15), chloramphenicol (30), SXT (sulphamethoxazole/trimethoprim, $27 \cdot 75+1 \cdot 25$ ), vancomycin (5) and penicillin (10), but were sensitive to amoxicillin (25), cephalothin (30), kanamycin (30), nalidixic acid (30), tetracycline (30), streptomycin (10), neomycin (30) and gentamicin (10).

Cell extract preparation and enzyme activity measurements were conducted as described by Miller et al. (2005). In addition, tests for methanol dehydrogenase were conducted in the presence of NAD $(1 \mathrm{mM})$ as an electron acceptor, at $\mathrm{pH} 7$ and 9.5. Methanol oxidase was assayed in the following reaction mixture $(1 \mathrm{ml}): 50 \mathrm{mM} \mathrm{MOPS} / \mathrm{KOH}$ buffer $(\mathrm{pH} 7 \cdot 5), 0 \cdot 17 \mathrm{mM}$ o-dianisidine, $5 \mathrm{mM}$ methanol, $2 \mathrm{U}$ horseradish peroxidase $\mathrm{ml}^{-1}$ and cell extract (all reagents were from Sigma). Activity was monitored spectrophotometrically by observing absorbance at $436 \mathrm{~nm}$ $\left(\varepsilon_{o \text {-dianisidine }}=8.31 \times 10^{3} \mathrm{~mol} \mathrm{l}^{-1}\right.$; Bergmeyer et al., 1974 $)$. Tests for methanol dehydrogenase and methanol oxidase were negative. Tests for methylamine dehydrogenase in methylamine-grown cells were also negative. PCR amplification of the mxaF gene with specific primers (McDonald \& Murrell, 1997) produced negative results. Genes for the tetrahydromethanopterin-linked formaldehyde oxidation pathway ( $f a e$ and $f h c D$ ) were successfully amplified using the primers described by Kalyuzhnaya \& Chistoserdova (2005). No activities were detected for key enzymes of the ribulose monophosphate (RuMP) cycle for formaldehyde assimilation, but activities of key enzymes of the serine cycle (serine glyoxylate aminotransferase and hydroxypyruvate reductase) were found.
For fatty acid analysis, the strains were grown on trypticase soy agar (TSA; Difco). In general, the fatty acid profiles were similar for the three isolates (Table 1). The major fatty acids were $\mathrm{C}_{16: 1} \omega 7 c(51-56 \%)$ and $\mathrm{C}_{16: 0}(29-31 \%)$. Cyclopropaneoctanoic acid was detected only in strain FAM $^{\mathrm{T}}$. Fatty acid $\mathrm{C}_{19: 1} \omega 6 c$ was found in strains $\mathrm{FAM}^{\mathrm{T}}$ and 500, while $\mathrm{C}_{15: 0}$ was unique to strain $\mathrm{EHg} 5$ and $\mathrm{C}_{18: 0}$ was unique to strain 500. The major quinone of all three isolates was ubiquinone Q8. DNA $\mathrm{G}+\mathrm{C}$ contents were $63 \cdot 5 \pm 0 \cdot 6,65 \cdot 5 \pm 0 \cdot 5$ and $63 \cdot 9 \pm 0 \cdot 2 \mathrm{~mol} \%$ for isolates EHg5, FAM $5^{\mathrm{T}}$ and 500, respectively. The genomic relatedness of the new isolates was investigated using DNA-DNA hybridization. Isolates $\mathrm{FAM}^{\mathrm{T}}$ and 500 were shown to be closely related (93\% DNA-DNA relatedness), whereas isolate $\mathrm{EHg} 5$ shared only 44 and $59 \%$ relatedness with isolates $\mathrm{FAM} 5^{\mathrm{T}}$ and 500 , respectively.

Based on phylogenetic analysis of 16S rRNA gene fragment sequences, the three isolates were closely related to each other. The sequences for isolates $\mathrm{FAM}^{\mathrm{T}}$ and 500 were identical, and showed $99 \cdot 85 \%$ similarity with the sequence for isolate $\mathrm{EHg} 5$. The new isolates were only distantly related to the well-characterized methylotrophs of the family Methylophilaceae ( $<89 \%$ sequence similarity; Jenkins \& Doroty, 1987; Doronina et al., 2005) and to a recently characterized methylotroph within the Burkholderiales, Methylibium petroleiphilum $\mathrm{PM}^{\mathrm{T}}$ ( $<90 \%$; Nakatsu et al., 2006). Closest relationships to recognized bacteria were with the cholesterol-oxidizing denitrifier Sterolibacterium denitrificans Chol-1S ${ }^{\mathrm{T}}$ (93\%; Tarlera \& Denner, 2003) and the nitrogen-fixing Derxia gummosa IAM $13946^{\mathrm{T}}$ (92.8\%; Xie

Table 1. Fatty acid profiles and major quinones of strains EgH5, FAM5 ${ }^{\dagger}$ and 500 compared with those of Sterolibacterium denitrificans Chol-1S $\mathrm{S}^{\top}$

Values for fatty acids are percentages of total fatty acids. Data for $S$. denitrificans Chol- $1 \mathrm{~S}^{\mathrm{T}}$ were taken from Tarlera \& Denner (2003). RQ, Rhodoquinone; -, not detected; NR, not reported.

\begin{tabular}{|lcccc|}
\hline Component & EHg5 & FAM5 $^{\text {T }}$ & $\mathbf{5 0 0}$ & $\begin{array}{c}\text { S. denitrificans } \\
\text { Chol-1S }^{\text {T }}\end{array}$ \\
\hline Fatty acids & & & & \\
$\mathrm{C}_{10: 0} 3-\mathrm{OH}$ & $2 \cdot 7$ & $3 \cdot 3$ & $3 \cdot 0$ & $14 \cdot 0$ \\
$\mathrm{C}_{12: 0}$ & $3 \cdot 8$ & $3 \cdot 8$ & $3 \cdot 3$ & $5 \cdot 3$ \\
$\mathrm{C}_{12: 0} 3-\mathrm{OH}$ & $3 \cdot 1$ & $2 \cdot 6$ & $2 \cdot 3$ & $\mathrm{NR}$ \\
$\mathrm{C}_{14: 0}$ & $1 \cdot 7$ & $2 \cdot 1$ & $2 \cdot 3$ & $0 \cdot 9$ \\
$\mathrm{C}_{15: 0}$ & $0 \cdot 8$ & - & - & $0 \cdot 8$ \\
$\mathrm{C}_{16: 1} \omega 7 c$ & $56 \cdot 1$ & $51 \cdot 2$ & $52 \cdot 6$ & $33 \cdot 8$ \\
$\mathrm{C}_{16: 0}$ & $29 \cdot 0$ & $30 \cdot 2$ & $31 \cdot 1$ & $21 \cdot 5$ \\
$\mathrm{C}_{17: 0}$ cyclo & - & $2 \cdot 2$ & - & $\mathrm{NR}$ \\
$\mathrm{C}_{18: 0}$ & - & - & $0 \cdot 5$ & $\mathrm{NR}$ \\
$\mathrm{C}_{18: 1} \omega 7 c / 12 t / 9 t$ & $2 \cdot 8$ & $3 \cdot 8$ & $3 \cdot 6$ & $14 \cdot 5$ \\
$\mathrm{C}_{18: 1} \omega 9 c$ & - & - & $0 \cdot 5$ & $\mathrm{NR}$ \\
$\mathrm{C}_{19: 1} \omega 6 c$ & - & $0 \cdot 8$ & $0 \cdot 9$ & $\mathrm{NR}$ \\
Major quinone $(\mathrm{s})$ & $\mathrm{Q} 8$ & $\mathrm{Q} 8$ & $\mathrm{Q} 8$ & $\mathrm{Q}-8 / \mathrm{RQ}-8$ \\
\hline
\end{tabular}




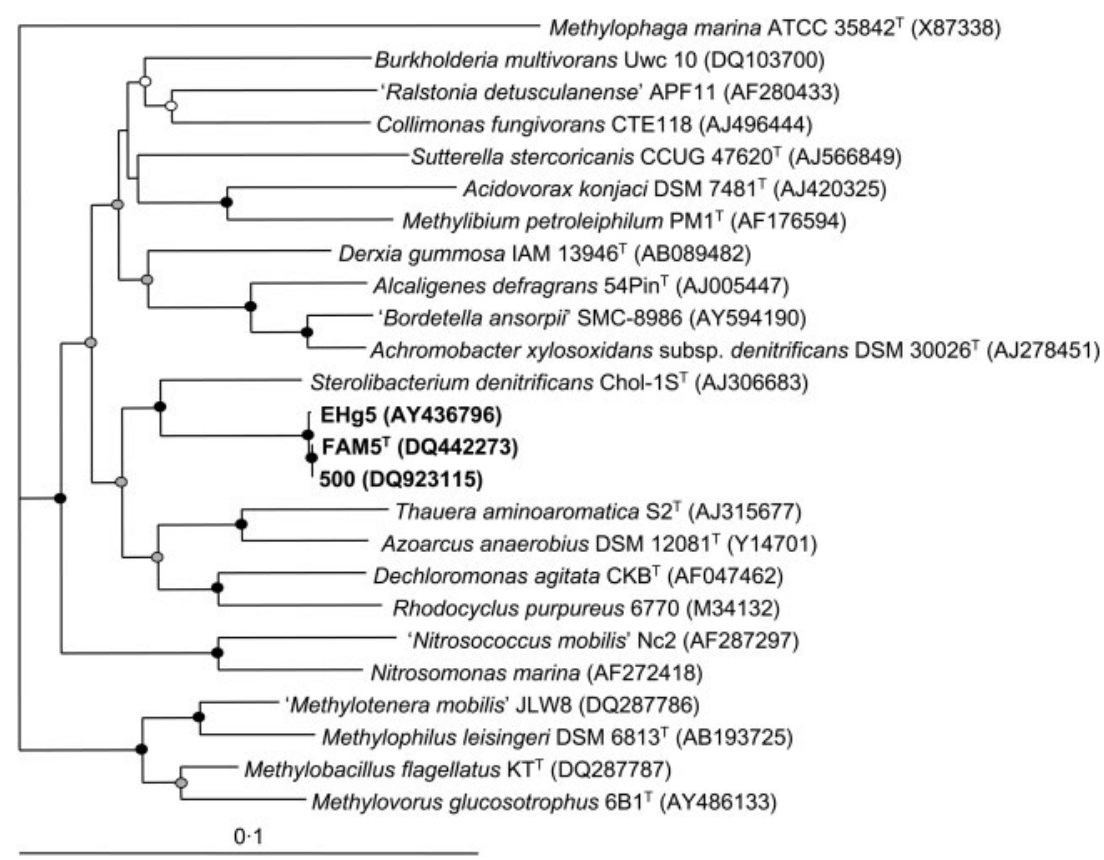

Fig. 2. Phylogenetic tree constructed using neighbour-joining analysis showing the positions of isolates $\mathrm{FAM}^{\mathrm{T}}, 500$ and $\mathrm{EHg} 5$ within the Betaproteobacteria, based on $16 \mathrm{~S}$ rRNA gene sequences. Strain numbers and GenBank accession numbers (in parentheses) are shown. Bootstrap support values of $>90 \%$ are indicated by filled circles, $70-90 \%$ by shaded circles and $55-70 \%$ by open circles. Bar, 10 substitutions per 100 nucleotide positions.
\& Yokota, 2004) (Fig. 2). However, the 16S rRNA gene sequences of the isolates characterized here were closely related (97-99\% sequence similarity) to a large number of sequences obtained from a variety of environmental samples, such as from drinking water (Williams et al., 2004), activated sludge (Loy et al., 2005), biofilms (Cole et al., 2004), gold and diamond mines (GenBank accession no. AY187895), subsurface waters (accession no. DQ336969), contaminated groundwater (Connon et al., 2005) and soils (accession no. AM159490). With regard to cultivable unclassified members of the Rhodocyclaceae, the three isolates were closely related to isolates HTCC379 (99\% sequence similarity), W8 (99\%) (Connon et al., 2005) and Thauera sp. MG70 (98\%) (Gomila et al., 2005).

Many members of the family Rhodocyclaceae possess biotechnological or agricultural potential, such as the ability to degrade halogenated compounds (Song et al., 2000), enhanced biological phosphate removal (Bond et al., 1995), denitrification and reduction of (per)chlorates (Achenbach et al., 2001; Coates et al., 1999) and nitrogen fixation (Xie \& Yokota, 2004). It was shown that species of the Rhodocyclales represent the majority of bacterial populations in waste-treatment plants and bioreactors (Bond et al., 1995; Juretschko et al., 2002); however, none has yet been characterized as showing methylotrophy, and many members of the Rhodocyclales have been assumed to be recalcitrant to cultivation (Loy et al., 2005). Cultureindependent studies of bacteria from Lake Washington employing PCR surveys (Nercessian et al., 2005; Kalyuzhnaya \& Chistoserdova, 2005) or metagenomic analysis (Kalyuzhnaya et al., 2005b) have indicated that a broad group of members of the Betaproteobacteria not closely related to any known methylotrophic groups represented a significant portion of the total microbial community. Routine strategies for isolating methylotrophic bacteria, employing classic $\mathrm{C}_{1}$ substrates such as methanol, methylamine or formate, have not resulted in enrichment of the betaproteobacteria in question, as they were readily out-competed by the well-characterized methylotrophic 'specialists', members of the genera Methylophilus, Methylopila, Methylobacterium and Ralstonia (M. G. Kalyuzhnaya, unpublished results). However, betaproteobacterial species related to members of the Burkholderiales and Rhodocyclales were enriched after supplementation of LWW with formaldehyde solution. Experiments with the resulting pure cultures demonstrated that all these isolates could utilize a broad range of $\mathrm{C}_{1}$ compounds, as exemplified by the strains described here. Therefore, our data indicate that supplementation with formaldehyde and/or vitamin $B_{12}$ could be used for selective enrichment of methylotrophic representatives of the Burkholderiales and Rhodocyclales from complex microbial communities.

Although the new isolates grew on $\mathrm{C}_{1}$ compounds at rates similar to those reported for representatives of the Methylophilaceae, we were not able to detect activities of typical primary oxidation enzymes such as methanol dehydrogenase or methylamine dehydrogenase, by using standard assay conditions. These results suggest that these novel methylotrophs may possess alternative primary oxidation systems. The isolates described here also differ from representatives of the Methylophilaceae by possessing activities of the serine cycle enzymes but lacking activities of key enzymes of the RuMP cycle. The methylotrophic representative of the Burkholderiales, Methylibium petroleiphilum, also possesses the genes for the serine cycle and lacks key genes of the RuMP cycle (K. Hristova, personal communication). Analysis of the genome of Methylibium petroleiphilum $\mathrm{PM}^{\mathrm{T}}$ 
(http://genome.jgi-psf.org/finished_microbes/metpe/metpe. home.html) showed that it lacks the typical mxaFJGI gene cluster encoding the subunits of methanol dehydrogenase and the associated cytochrome $c$ (M. G. Kalyuzhnaya and L. Chistoserdova, unpublished). These results indicate that the metabolic patterns of $\mathrm{C}_{1}$ utilization of the new isolates must be similar to those of representatives of the Rhodocyclales and Burkholderiales, but they differ significantly from the typical metabolic scheme employed by representatives of the Methylophilaceae. In contrast to other members of the family Rhodocyclaceae, the isolates described here were not able to fix nitrogen or to reduce nitrate.

The low 16S rRNA gene sequence similarity with recognized members of the Betaproteobacteria $(<94 \%)$ warrants the placement of the strains described here within a new genus within the family Rhodocyclaceae. Although isolate $\mathrm{EHg} 5$ shared relatively low levels of DNA-DNA relatedness with the two Lake Washington isolates, the phenotypic and metabolic characteristics of the three isolates were very similar. Based on these results, we propose that all three strains represent a single taxon within the Rhodocyclaceae, for which we propose the name Methyloversatilis universalis gen. nov., sp. nov.

\section{Description of Methyloversatilis gen. nov.}

Methyloversatilis [Me.thy'lo.ver.sa.ti'lis. N. Gr. n. methyl (from Gr. n. methu wine and Gr. n. hulê wood) methyl radical; L. adj. versatilis versatile; N.L. fem. n. Methyloversatilis versatile methyl (utilizer), reflecting the versatile trophic abilities of the first isolates].

Cells are Gram-negative, non-motile rods that multiply by binary fission. Able to utilize a variety of $\mathrm{C}_{1}$ and multicarbon compounds. Assimilate $C_{1}$ units via the serine pathway. The major fatty acids are $\mathrm{C}_{16: 1} \omega 7 \mathrm{c}$ and $\mathrm{C}_{16: 0}$. The major quinone is Q8. The $\mathrm{G}+\mathrm{C}$ content of the DNA is $64-65 \mathrm{~mol} \%$. The type and only species is Methyloversatilis universalis.

\section{Description of Methyloversatilis universalis sp. nov.}

Methyloversatilis universalis (u.ni.ver.sa'lis. L. fem. adj. universalis universal, reflecting the ubiquitous distribution of the first isolates in the environment).

Cells are $1 \cdot 2 \pm 0 \cdot 4 \times 0 \cdot 4 \pm 0 \cdot 1 \mu \mathrm{m}$ in size and occur singly or in pairs. Growth occurs at $\mathrm{pH} 6-9$, with optimal growth at $\mathrm{pH} 7 \cdot 5-8$. Temperature optimum is $30-37^{\circ} \mathrm{C}$. Utilizes methanol, methylated amines, formaldehyde and formate, as well as a variety of multicarbon compounds. Oxidase- and catalase-positive. Negative for nitrate reduction, urease activity, sugar fermentation and indole production. Resistant to ampicillin, erythromycin, chloramphenicol, SXT, vancomycin and penicillin, but sensitive to amoxicillin, cephalothin, kanamycin, nalidixic acid, tetracycline, streptomycin, neomycin and gentamicin.

The type strain, FAM $^{\mathrm{T}}\left(=\right.$ CCUG $\left.52030^{\mathrm{T}}=\mathrm{JCM} 13912^{\mathrm{T}}\right)$, was isolated from freshwater Lake Washington (USA).

\section{Acknowledgements}

This research was supported by a grant (MCB-0131957) from the NSF Microbial Observatories Program and by Project FP QLK5-CT2000-01528 of the European Commission.

\section{References}

Achenbach, L. A., Michaelidou, U., Bruce, R. A., Fryman, J. \& Coates, J. D. (2001). Dechloromonas agitata gen. nov., sp. nov. and Dechlorosoma suillum gen. nov., sp. nov., two novel environmentally dominant (per)chlorate-reducing bacteria and their phylogenetic position. Int J Syst Evol Microbiol 51, 527-533.

Bergmeyer, H. U., Gawehn, K. \& Grassl, M. (1974). Enzymes as biochemical reagents. Glucose oxidase. In Methods of Enzymatic Analysis, 2nd edn, vol. I, pp. 457-458. Edited by H. U. Bergmeyer. New York: Academic Press.

Bond, P. L., Hugenholtz, P., Keller, J. \& Blackall, L. L. (1995). Bacterial community structures of phosphate-removing and nonphosphate-removing activated sludges from sequencing batch reactors. Appl Environ Microbiol 61, 1910-1916.

Coates, J. D., Michaelidou, U., Bruce, R. A., O’Connor, S. M., Crespi, J. N. \& Achenbach, L. A. (1999). Ubiquity and diversity of dissimilatory (per)chlorate-reducing bacteria. Appl Environ Microbiol 65, 5234-5241.

Cole, A. C., Semmens, M. J. \& LaPara, T. M. (2004). Stratification of activity and bacterial community structure in biofilms grown on membranes transferring oxygen. Appl Environ Microbiol 70, 19821989.

Connon, S. A., Tovanabootr, A., Dolan, M., Vergin, K., Giovannoni, S. J. \& Semprini, L. (2005). Bacterial community composition determined by culture-independent and -dependent methods during propane-stimulated bioremediation in trichloroethene-contaminated groundwater. Environ Microbiol 7, 165-178.

De Marco, P., Pacheco, C. C., Figueiredo, A. R. \& Moradas-Ferreira, P. (2004). Novel pollutant-resistant methylotrophic bacteria for use in bioremediation. FEMS Microbiol Lett 234, 75-80.

Doronina, N. V., Ivanova, E. G. \& Trotsenko, Y. A. (2005). Phylogenetic position and emended description of the genus Methylovorus. Int J Syst Evol Microbiol 55, 903-906.

Felsenstein, J. (2003). Inferring Phylogenies. Sunderland, MA: Sinauer Associates.

Gomila, M., Gasco, J., Busquets, A., Gil, J., Bernabeu, R., Buades, J. M. \& Lalucat, J. (2005). Identification of culturable bacteria present in haemodialysis water and fluid. FEMS Microbiol Ecol 52, 101-114.

Harder, W., Attwood, M. \& Quayele, J. R. (1973). Methanol assimilation by Hyphomicrobium spp. J Gen Microbiol 78, 155-163. Higgins, D. G., Thompson, J. D. \& Gibson, T. J. (1996). Using CLUSTAL for multiple sequence alignments. Methods Enzymol 266, 383-402.

Jenkins, O. \& Doroty, J. (1987). Taxonomic studies on some gramnegative methylotrophic bacteria. J Gen Microbiol 133, 453-473.

Johnson, J. L. (1994). Similarity analysis of DNAs. In Methods for General and Molecular Bacteriology, pp. 655-681. Edited by P. Gerhardt, R. G. E. Murray, W. A. Wood \& N. R. Krieg. Washington, DC: American Society for Microbiology.

Juretschko, S., Loy, A., Lehner, A. \& Wagner, M. (2002). The microbial community composition of a nitrifying-denitrifying activated sludge from an industrial sewage treatment plant analyzed by the full-cycle rRNA approach. Syst Appl Microbiol 25, 84-99. 
Kalyuzhnaya, M. G. \& Chistoserdova, L. (2005). Community-level analysis: genes encoding methanopterin-dependent enzymes. Methods Enzymol 397, 443-454.

Kalyuzhnaya, M. G., Lidstrom, M. E. \& Chistoserdova, L. (2004). Utility of environmental primers targeting ancient enzymes: methylotroph detection in Lake Washington. Microb Ecol 48, 463-472.

Kalyuzhnaya, M. G., Stolyar, S. M., Auman, A. J., Lara, J. C., Lidstrom, M. E. \& Chistoserdova, L. (2005a). Methylosarcina lacus sp. nov., a methanotroph from Lake Washington, Seattle, USA, and emended description of the genus Methylosarcina. Int J Syst Evol Microbiol 55, 2345-2350.

Kalyuzhnaya, M. G., Bowerman, S., Nercessian, O., Lidstrom, M. E. \& Chistoserdova, L. (2005b). Highly divergent genes for methanopterin-linked $C_{1}$ transfer reactions in Lake Washington, assessed via metagenomic analysis and mRNA detection. Appl Environ Microbiol 71, 8846-8854.

Lane, D. J. (1991). 16S/23S rRNA sequencing. In Nucleic Acid Techniques in Bacterial Systematics, pp. 115-175. Edited by E. Stackebrandt \& M. Goodfellow. New York: Wiley.

Lidstrom, M. E. (2001). Aerobic methylotrophic prokaryotes. In The Prokaryotes: an Evolving Electronic Resource for the Microbiological Community, release 3.7. Edited by M. Dworkin and others. New York: Springer. http://link.springer-ny.com/link/service/books/10125/

Loy, A., Schulz, C., Lücker, S., Schöpfer-Wendels, A., Stoecker, K., Baranyi, C., Lehner, A. \& Wagner, M. (2005). 16S rRNA gene-based oligonucleotide microarray for environmental monitoring of the betaproteobacterial order "Rhodocyclales". Appl Environ Microbiol 71, 1373-1386.

McDonald, I. R. \& Murrell, J. C. (1997). The methanol dehydrogenase structural gene mxaF and its use as a functional gene probe for methanotrophs and methylotrophs. Appl Environ Microbiol 63, 3218-3224.

Miller, J. A., Kalyuzhnaya, M. G., Noyes, E., Lara, J. C., Lidstrom, M. E. \& Chistoserdova, L. (2005). Labrys methylaminiphilus sp. nov., a novel facultatively methylotrophic bacterium from a freshwater lake sediment. Int J Syst Evol Microbiol 55, 1247-1253.
Nakatsu, C. H., Hristova, K., Hanada, S., Meng, X.-Y., Hanson, J. R., Scow, K. M. \& Kamagata, Y. (2006). Methylibium petroleiphilum gen. nov., sp. nov., a novel methyl tert-butyl ether-degrading methylotroph of the Betaproteobacteria. Int J Syst Evol Microbiol 56, 983-989.

Nercessian, O., Noyes, E., Kalyuzhnaya, M. G., Lidstrom, M. E. \& Chistoserdova, L. (2005). Bacterial populations active in metabolism of $\mathrm{C}_{1}$ compounds in the sediment of Lake Washington, a freshwater lake. Appl Environ Microbiol 71, 6885-6689.

Smibert, R. M. \& Krieg, N. R. (1994). Phenotypic characterization. In Methods for General and Molecular Bacteriology, pp. 611-654. Edited by P. Gerhardt, R. G. E. Murray, W. A. Wood \& N. R. Krieg. Washington, DC: American Society for Microbiology.

Song, B., Palleroni, N. J. \& Häggblom, M. M. (2000). Isolation and characterization of diverse halobenzoate-degrading denitrifying bacteria from soils and sediments. Appl Environ Microbiol 66, 3446-3453.

Tamaoka, J. \& Komagata, K. (1984). Determination of DNA base composition by reversed-phase high-performance liquid chromatography. FEMS Microbiol Lett 25, 125-128.

Tarlera, S. \& Denner, E. B. M. (2003). Sterolibacterium denitrificans gen. nov., sp. nov., a novel cholesterol-oxidizing, denitrifying member of the $\beta$-Proteobacteria. Int $J$ Syst Evol Microbiol 53, 1085-1091.

Willems, A., Goor, M., Thielemans, S., Gillis, M., Kersters, K. \& De Ley, J. (1992). Transfer of several phytopathogenic Pseudomonas species to Acidovorax as Acidovorax avenae subsp. avenae subsp. nov., comb. nov., Acidovorax avenae subsp. citrulli, Acidovorax avenae subsp. cattleyae, and Acidovorax konjaci. Int J Syst Bacteriol 42, 107-119.

Williams, M. M., Domingo, J. W., Meckes, M. C., Kelty, C. A. \& Rochon, H. S. (2004). Phylogenetic diversity of drinking water bacteria in a distribution system simulator. J Appl Microbiol 96, 954-964.

Xie, C. \& Yokota, A. (2004). Phylogenetic analyses of the nitrogenfixing genus Derxia. J Gen Appl Microbiol 50, 129-135. 